Y. LIU,* X. XI, C. YE, T. GONG, Z. YANG, Y. CUI* (SHANGHAi JIAO TONG UNIVERSITY AND COLLABORATIVE INNOVATION CENTER OF CHEMICAL SCIENCE AND ENGINEERING, TIANJIN, P. R. OF CHINA)

Chiral Metal-Organic Frameworks Bearing Free Carboxylic Acids for Organocatalyst Encapsulation Angew. Chem. Int. Ed. 2014, 53, 13821-13825.

\section{MOFs Bearing Free Carboxylic Acids for Organocatalyst Encapsulation}

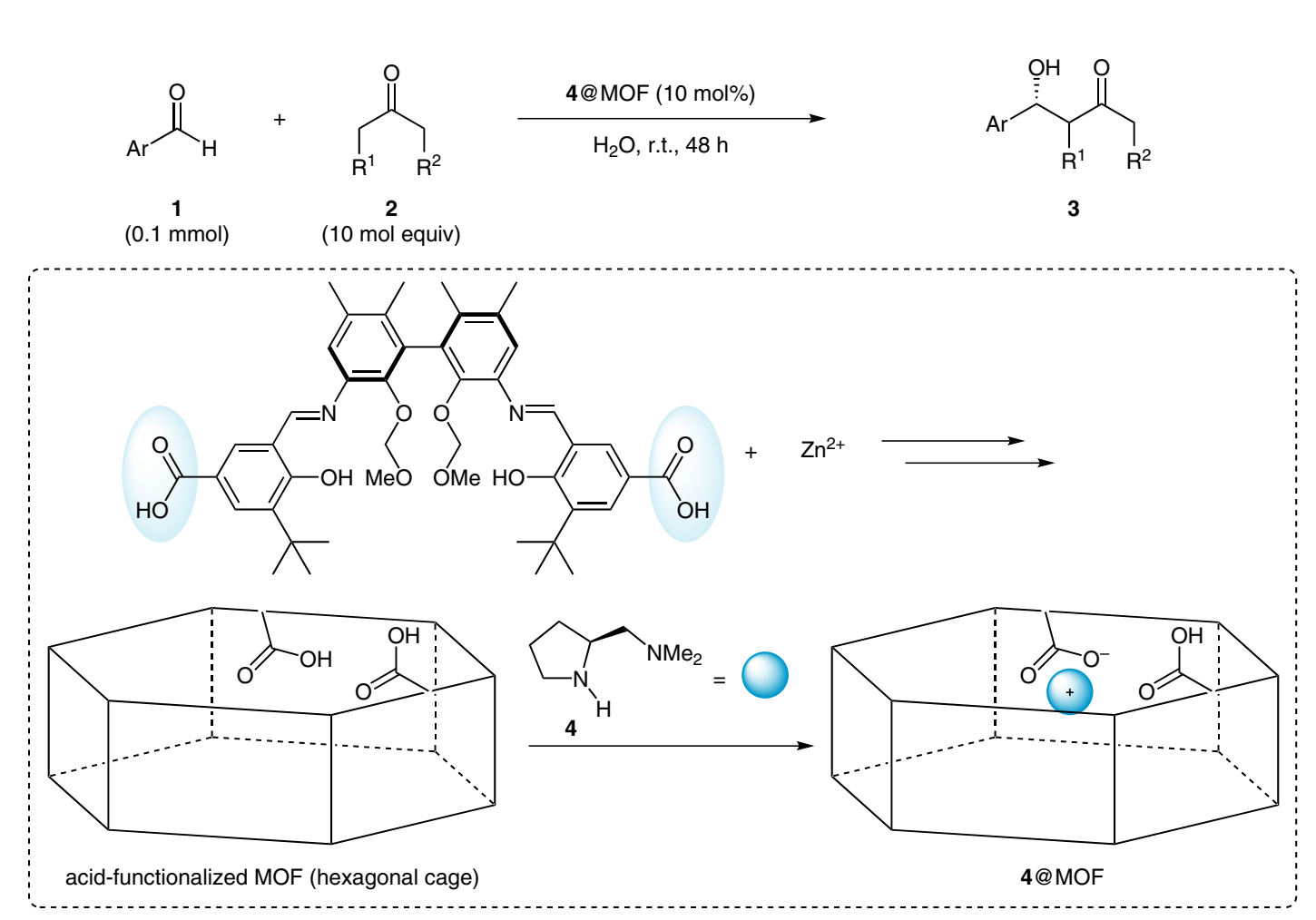

\section{Gategory}

Polymer-Supported Synthesis

\section{Key words}

aldol reaction

heterogeneous catalysis

metal-organic framework

organocatalysis

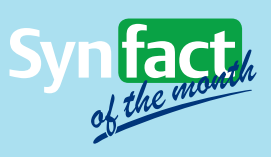

Selected examples:<smiles>CC(=O)C[C@H](O)c1ccc([N+](=O)[O-])cc1</smiles>

$77 \%$ yield, $80 \%$ ee<smiles>CC(=O)C[C@H](O)c1cccc([N+](=O)[O-])c1</smiles>

$73 \%$ yield, $74 \%$ ee<smiles>O=C1CCCCC1[C@H](O)c1ccc([N+](=O)[O-])cc1</smiles>

$72 \%$ yield, $74 \%$ ee anti/syn $=3.3: 1.0$<smiles>O=C1CCCCC1[C@H](O)c1cccc([N+](=O)[O-])c1</smiles>

$68 \%$ yield, $66 \%$ ee anti/syn $=2.0: 1.0$
Significance: Carboxylic acid functionalized micro- and mesoporous metal-organic frameworks (MOFs) were developed for the organocatalyst encapsulation via acid-base interactions. The reaction of aldehydes $\mathbf{1}$ with ketones $\mathbf{2}$ in the presence of $\mathbf{4} @$ MOF (encapsulated $\mathbf{4}$ in acid-functionalized MOF) proceeded in water to give the aldol products 3 in $68-77 \%$ yield with $66-80 \%$ ee.
Comment: The MOF-based catalyst 4@MOF gave higher enantioselectivity than the combination of $\mathbf{4}$ and benzoic acid as homogeneous counterparts. Thus, the reaction of 4-nitrobenzaldehyde and acetone in the presence of $\mathbf{4}$ with benzoic acid (1 mol equiv) afforded the corresponding product 3 in $79 \%$ yield with 64\% ee (cf. 4@MOF: $77 \%$ yield, $80 \%$ ee).

SYNFACTS Contributors: Yasuhiro Uozumi, Yoichi M. A. Yamada, Takuma Sato

Dol: 10.1055/s-0034-1380253; Reg-No.: Y00515SF 